\title{
A dança entre grupos tradicionais e o imaginário mítico para sua constituição
}

\author{
La danza entre grupos tradicionales y el imaginario mítico para su \\ constitución.
}

\author{
Dance between traditional groups and the mythical imagination is its \\ constitution
}

Cláudio Batista Carle ${ }^{1}$

\begin{abstract}
Resumo
O texto que apresento é fruto de um contexto exploratórios de manifestações dançadas específicas de grupos que posso considerar tradicionais eu de manifestações tradicionais de grupos no Brasil. Os grupos estudados são os ameríndios e as sociedades africanas arrastadas para a América que desenvolveram uma série de danças espelhadas no imaginário mítico tradicional. A forma de aproximação com estas danças foi feita a partir da "aura do imaginário" do Círculo de Eranos. O Imaginário estudado pelo Circulo de Eranos, inicialmente na Europa, investigou sistemas míticos que já estavam escritos, mas quando nos deparamos com as sociedades tradicionais no Brasil verifica-se que estas míticas são vivas e em constante transformação, sem contudo perder suas bases simbólicas originais. O imaginário me possibilita identificar as bases simbólicas que formaram as míticas que apresentam as imagens que se buscam manter nessas sociedades em destaque. Neste trabalho apresento alguns exemplos destas míticas, dos símbolos originais e as formaram a partir da investigação da externalização dessas, que eu chamo de apresentação. Estudando esses contextos étnicos tradicionais é possível verificar a persistência simbólica, que possibilita manter a própria tradição e com isso perpetuar sua identidade étnica. Foquei nas "danças afro" desenvolvidas no sul do Brasil e algumas manifestações dançadas dos ameríndios do sul e do norte do Brasil. Estas danças são hoje reconhecidamente danças de expressão da persistência, das formas de pensar e agir, com/no mundo, dessas comunidades, na contraposição ao contexto simbólico trazido pelos invasores europeus, transformando estas danças em manifestações socioculturais de resistência dos afro-americanos e ameríndios.
\end{abstract}

Palavras chave: Danças tradicionais, Imaginário, Ameríndios, Afroamericanos

\section{Resumen}

El texto que presento es el resultado de un contexto exploratorio de manifestaciones de danza grupales específicas que puedo considerar manifestaciones grupales tradicionales y tradicionales en Brasil. Los grupos estudiados son los amerindios y las sociedades africanas arrastradas a América que desarrollaron una serie de danzas reflejadas en el imaginario mítico tradicional. El acercamiento a estos bailes se hizo desde el "aura de la imaginación" del Círculo de Eranos. El Imaginario estudiado por el Círculo de Eranos, inicialmente en Europa, investigó los sistemas míticos que ya estaban escritos, pero cuando nos encontramos con las sociedades tradicionales en Brasil, parece que estos mitos están vivos y cambian constantemente, sin perder sus bases simbólicas originales. . La imaginación me permite identificar las bases simbólicas que formaron los mitos que presentan las imágenes que buscan mantener en estas sociedades prominentes. En este artículo presento algunos ejemplos de estos mitos, los símbolos originales y los formé a partir de la investigación de su externalización, que llamo presentación. Al estudiar estos contextos étnicos tradicionales es posible verificar la persistencia simbólica, lo que hace posible mantener la propia tradición y perpetuar su identidad étnica. Me concentré en las "danzas afro" desarrolladas en el sur de Brasil y en algunas manifestaciones bailadas de los amerindios del sur y norte de Brasil. Estas danzas son hoy en día danzas que expresan la persistencia, las formas de pensar y actuar, con / en el mundo, de estas comunidades, en oposición al contexto simbólico traído por los invasores europeos,

1 Doutor História-Arqueologia, PPGH/UFRGS-Pós-doutorando; PPGAnt-UFPEL; DAA-ICH-UFPEL; cbcarle@yahoo.com.br 
transformando estas danzas en manifestaciones socioculturales de resistencia de afroamericanos y amerindios.

Palabras clave: Bailes tradicionales, Imaginarios, Amerindios, Afroamericanos

\begin{abstract}
The text I present is the result of an exploratory context of specific group dance demonstrations that I can consider traditional and traditional group manifestations in Brazil. The studied groups of Amerindian and African societies dragged the United States, which developed a series of dances reflected in traditional mythical images. The focus of these dances is based on the "aura of imagination" of the Eranos Circle. The Imaginary studied by the Eranos Circle, initially in Europe, investigates the mythical systems that were written, but when we find traditional societies in Brazil, it seems that these myths are constantly alive and changing, without losing their original symbolic bases. . Imagination allows me to identify the symbolic bases that formed the myths that present the images that they seek to maintain in these prominent societies. In this article, I present some examples of these myths, the original symbols and the forms of investigation of their outsourcing, which I will present. Studying these traditional ethnic contexts is possible to verify the symbolic persistence, that it is possible to maintain its own tradition and perpetuate its ethnic identity. I focus on the "African dance" developed in Brazil and on some dance demonstrations of Native Americans from the south and north of Brazil. These dances are today in the dances that express persistence, the ways of thinking and acting, with the world, of these communities, in opposition to the symbolic context betrayed by the European invaders, transforming these dances into socio-cultural expressions of resistance by African-Americans. . and Native Americans.
\end{abstract}

Keywords: traditional, imaginary, native american, african american balls

\title{
1.A dança entre grupos tradicionais e o imaginário mítico para sua constituição
}

O estudo de sociedades tradicionais tem sido um campo fértil de atividade da antropologia. Essa tem se valido para tanto da inserção em campo e a partir de conceitos específicos a realização das interpretações sobre essas sociedades. A tradição do estudo sobre as imagens tem sido tratada como forma de apropriação ou captura de informações como diários de campo imagéticos, como formas visuais, das manifestações destes grupos. No entanto o que busco é uma profundidade do que é superficial nesses sistemas de investigação. Buscamos no GPCIE (Grupo de Pesquisa Cultura, Imaginário, Educação) investigar é a alma destas imagens. A aura do Imaginário do Círculo de Eranos é um início de caminhada. As interpretações que estudam as mentalidades destes grupos e com isso as formas imagéticas de compreender o mundo são relegadas em grande parte, mas é isso que buscamos. O Circulo de Eranos, onde escritores como Bachelard, Jung, Durand, Ortiz-Osés, e outros no passado, e atualmente Machado da Silva, Maffesoli, Morin, Araujo e outros, dedica-se a entender como as imagens mentais explicam o mundo dentro das culturas. Estes pesquisadores, no entanto, tratam de um mundo escrito em primeira instância, mas como nos dedicamos a entender grupos humanos vivos e em constante apresentação do se ser no mundo, tencionamos a necessidade de inventariar estes contextos de apresentação da imagem, para então ingressas ao submundo de sua constituição.

A situação peculiar, em que nos encontramos, é que na América Latina ainda não há muitos inventários míticos dos povos autoctones, nem das populações exógenas, tanto aquelas 
arrastadas para cá, quanto para as europeias. No entanto as europeias, por tradição, tentam promover o seu imaginário original, mesmo que consideremos as influências locais, tornandoas mais próximas dos criadores deste sistema de investigação. Ou seja, estão de certa forma escrita e ligadas a míticas traduzidas em textos míticos já consagrados em inventários.

No Brasil a pesquisadora do Imaginário, que eu considero até o momento a mais capacitada para tratar deste campo é Danielle Pitta. Iniciada na cosmogonia africana faz emergir os saberes que são vivenciados por estes grupos, e espelhado nela, faço esse percurso. Pitta (2018, p 155) indica que para a compreensão em profundidade do imaginário brasileiro “é necessário ter acesso ao nível mítico a eles subjacentes". Esforço que realizo a partir dos métodos indicados por esta aura imaginante, que supre "uma necessidade importante quando se trata de lidar com o símbolo" (Pitta, 2018, p. 155).

A constituição de uma mítica, parte integrante do imaginário, e por tanto integrante da identidade de uma população etnicamente constituída, cria a dinâmica que varia no tempo. Cada cultura, ou cada etnia, mais especificamente, constituída por cada indivíduo, como ente cultural, constituído na cultura, se locomove "no seu próprio eixo", constrói "o seu trajeto", vive "seu próprio destino", atraído por um ou mais polos de imagens "segundo as circunstâncias"(Pitta, 2018, p. 160-161). Os polos mais contrastantes são o polo diurno, na imagem do herói, e o polo noturno, na estrutura mítica, sendo complementares (Pitta, 2018, p. 160-161).

A lógica não excludente das "polarizações" cria uma dinâmica, dependendo do "trajeto antropológico" (Durand, 2012), esse é um "incessante intercâmbio existente, a nível do imaginário, entre as pulsões subjetivas e assimiladoras e as intimações objetivas emanando do meio cósmico e social" (DURAND, 2012, p. 38). Aqui posso associar a corporeidade humana e a dança como um jogo, de polaridades, e me baseando em Pitta (2018) poderia dizer que há um trajeto dançado no incessante intercâmbio ao nível do imaginário, entre as pulsões heroicas e as pulsões míticas, emanando do corpo físico e social dos dançarinos, expressando a corporeidade e o cogito corporal, num paralelismo entre místico e heroico (Pitta, 2018 p.160).

Ressalta Pitta (2018, p. 154-155), que não existe separação entre os cenários significativos das mitologias tradicionais e o "agenciamento moderno dos relatos culturais". Ou seja, o mito tradicional torna-se relato atual, neste caso um relato do corpo e da musicalidade. Há sempre uma "continuidade entre o imaginário mítico e a positividade histórica". O pesquisa dor deve observar então "os comportamentos concretos", dos dançarinos, aproximando de seus "comportamento histórico", que "repetem com timidez, os 
cenários e as situações dramáticas dos grandes mitos" (Durand, 2012, apud Pitta, 2018, p. 154-155). Ou seja, no desenvolver o trajeto o desenvolve a partir de sua história, que é calcada nos mitos fundadores e nas suas alterações no processo de interação como mundo vivido.

O estudo trata de duas formas de apresentação destas manifestações, uma em sociedade poliétnica (citadina) e outra em sociedade tradicional autóctone, (ameríndia, indígena). Apresento diretamente os sistemas de expressão da resistência cultural, contra a opressão advinda sociedade envolvente poliétnica e que busca, através de uma ideia de homogeneizadora, constituir uma sociedade única de iguais, brancos e eurocentrados. O grupo em cultural em resistência, na vivência polietnica, apresenta uma reação e o grupo tradicional outra. Sobre estes casos apresento a seguir a interação a partir das paisagens sonoras, nas danças e músicas desenvolvidas e verifico suas míticas constituidoras. Os dançarinos e dançarinas se apresentam de forma heroica, ao dançar, marcados/as pelas míticas que sustentam esses atos.

A paisagem sonora dos cantos e danças revelam as marcas indeléveis da música (Borges, 2015). Os estudos desses contextos identificam sentidos do aparecer das culturas (Heiddeger, 1968) através da musicalidade (Borges, 2015). Uma é a tradução, onde a música está ao centro da manifestação, ocupa o centro da "cadeia intersemiótica do ritual", integra os "discursos verbais, olfativos, visuais e oriundos de outros canais sensórios" (Borges, 2015). A música é sentida, dizendo em outras palavras, mas para sentir é necessário ser do grupo, para conhecer o que sente. Noutro sentido percebe-se que os processos são realizados de forma redundante, formam uma unicidade conhecida, "a sequencialidade faz com que os repertórios musicais organizem-se em sequências (e sequências de sequências) de cânticos, ordenadas temporalmente pelos ciclos diários e sazonais" (Borges, 2015, 23). Ordenações necessárias a forma de reconhecimento e perpetuação de uma ordem cósmica, que é revelada no ato de cantar, tocar, dançar. E no terceiro sentido estão as características que estruturam o "núcleoperiferia, que remete a formações musico-coregráficas dos grupos executantes" (idem).

A ordem dos executores é controlada pela própria ordem mítica intrínseca a performática. Os indivíduos atuam de forma ordenada, que está na base do ritual, que o sustenta, o histórico e o mito. Noutro sentido estão as variações "dos motivos temáticos das peças musicais que, elaborados através de procedimentos da repetição, são executadas com aumentação, diminuição, transposição, retrogradação e outros” (Borges, 2015, p. 23). Nada é feito sem esses processos, que são enfaticamente ensinados e perpetuados, conforme as bases iniciais dos significados rituais, que tem como essência a mítica constituidora (Cassirer, 
1992).

Os ameríndios e afro-americanos, no entanto, possuem poucos inventários míticos, pois na tradição ocidental (eurocentrada), os "mitos destes povos", são "menores", e assim tratados muitas vezes como "lendas" ou nem mesmo tratados. O inventário está ainda para acontecer. Alguns estudos etnográficos e etno-históricos nos possibilitam entender alguns destes ensinamento sobre a forma de pensar e se sentir no mundo. Esta mítica está expressa nas suas formas de fazer e de viver. Umas dessas formas é a musicalidade e a dança.

A forma de aproximação com estas danças foi feita a partir da "aura do imaginário" do Círculo de Eranos. O Imaginário estudado pelo Circulo de Eranos, inicialmente na Europa, investigou sistemas míticos que já estavam escritos, mas quando nos deparamos com as sociedades tradicionais (cf. Barth, 1998), no Brasil, verifica-se que estas míticas são vivas e em constante transformação, sem contudo perder suas bases simbólicas originais. O imaginário me possibilita identificar as bases simbólicas que formaram as míticas que apresentam as imagens que se buscam manter nessas sociedades em destaque.

Aqui trago um contexto exploratório, de manifestações dançadas, específicas de grupos, que posso considerar tradicionais, ou manifestações tradicionais de grupos no Brasil. A ideia de tradicional é um ideia que postula a permanência de uma bacia semântica (Durand, 2012) ou bases de novas bacias semânticas do trajetos antropológicos de grupos humanos ainda não desorganizados pelo universo do capital e do consumo, ou seja, grupos cujas estruturas de formação são calcadas em organizações míticas pré-capitalistas. Negam o uniformalização e globalização para se constituírem. Conservam sistemas de transmissão de valores que são mantidos oralmente e por formas de fazer, que não, pressupõem, as ordenações homogeneizantes que vinculam-se a modelações de massa.

Os ensaios de estudo que não chegam ainda ao cerne destes grupos, pois dependem de maior aprofundamento. Os grupos estudados, os ameríndios e as sociedades africanas arrastadas para a América, desenvolveram uma série de danças espelhadas no imaginário mítico tradicional.

A antropologia nos indica que a música e a dança são capazes de expor ao ente que está na cultura tradicional o seu enraizamento. Enraizar é um enraizar simbólico (Cassirer, 1968), onde a mitologia, como difusora do sentido da vida (Cassirer, 1992) desenvolve esse enraizamento no universo social (Lévi-Strauss,1991). A musica e a dança entranha esse enraizamento, surge dele e por ele se apresenta (Heiddeger, 1968), manifesta o ser em sua plenitude e apresenta o seu sistema mítico, portanto simbólico, dos valores que se pensa necessário manter. A música "pega pelas entranhas", provocando o ato da dança, que é ritual, 
que é a expressão do mito (Durand, 2012).

A marca de resistência cultural, pode deve ser sempre entendida na noção de fronteiras culturais (Barth, 1998). A ideia de resistir é persistir, no universo dos grupos étnicos dicotomizados. Os grupos tradicionais evitam as trocas de pessoas, a mescla de padrões, persistem nos modos de subsistência, controle dos meios de produção; isso ocorre entre grupos nômades, camponeses, e mesmo entre citadinos onde os traços diacríticos (Barth, 1998) e valores culturais mantidos. Os territórios de uso multiplo e multiétnico, reforçam os sentido de pertença, formam conjunto de regras de contato entre etnias, desenvolvem prescrições na concordância com códigos de valores, no preservar parte da cultura contra a mudança, no impedimento de interações com outros.

Os sinais ou signos manifestos entendidos como traços diacríticos (Barth, 1998), são valores fundamentais, criam padrões de moralidade e juízos, estes são ensinados ao coletivo, pois são os seus demarcadores étnicos. Aqui é evidente a presença de danças e musicas ritualísticas, pois são propagadoras destes valores. A presença constante de fronteiras éticas gera um certa interdependência na região de fronteira e no interior dos grupos, principalmente no caso dos grupos inseridos em espaços poliétnicos, como os afro-brasileiros. As diferenças culturais, padronizações esteriótipos, busca de estabilidade cultural, são sempre apregoadas nesses traços internos e tornam-se demarcadores.

\section{Os Krahô}

Nas comunidades de menor contato com grupos mais distintos, há uma perspectiva ecológica (Barth, 1998) com o uso de nichos distintos, monopólio sobre territórios e o uso de nichos recíprocos. Valem-se também de uma perspectiva demográfica com o equilíbrio numérico no território, tamanho absoluto em nicho natural único, tamanho relativo em nicho compartilhado, que se torna muito complexo no sistema poliétnico (citadinos).

O grupo étnico tradicional, de menor contato, a quem recorro é reconhecido como pertencente as Terras Baixas da América (Borges, 2015), o grupo tradicional dos Krahô. Os indígenas Krahô são um povo povo da região norte do Brasil, no Estado de Tocantins, vivendo nos municípios de Goiatins e Itacajá; são pertencentes ao ramo linguístico Timbira, da Família Linguística Jê, do Tronco Macro-Jê. Na maior área de Cerrado contínuo do Brasil, a Terra Indígena Kraolândia, está entre os municípios de Itacajá, Santa Maria, Recursolândia e Goiatins (Borges, 2015, p.24). O território Krahô foi demarcado pela Funai (Fundação Nacional do Índio) em 1990. São aproximadamente 3mil indígenas, em vinte e nove aldeias. Moravam noutra área e foram contactados no início século XIX, no sul do Maranhão nas 
proximidades do rio Balsas, onde criadores de gados, não indígenas, foram se estabelecendo, e em 1809 (Macedo, 2015, p. 16). Expulsos depois, para a atual reserva, eles sempre fazem incursões às suas terras originais.

$\mathrm{Na}$ terra original, a oeste do Tocantins, os Krahô mantiveram contato amistoso e firmaram uma aliança, mas sempre foram estigmatizados. Os Krahô receberam, no passado, apoio dos não indígenas, no combate a povos indígenas inimigos e ajudavam os fazendeiros na escravização desses. Tornaram-se "guardiões dos rebanhos dos fazendeiros", evitando o abigeato. Com o tempo esta relação amistosa foi se desgastando. Em 1944, suas aldeias foram atacadas de forma violenta e após o massacre, perpetrado por fazendeiros incomodados com a presença indígena e os constantes roubos de gado. A carne de gado substituíra a carne da caça e era consumida nas festas dos Krahô, acusados então de realizar os roubos (Borges, 2015, p.24), mesmo que fossem aliados dos fazendeiros, sabe-se que sempre foi a velha desculpa para matar e ocupar as terras. As festas que incluem então a carne de gado é parte do sistema simbólico, e a luta pelas terras e o fato do massacre é ritualizada, para manter sua lembrança do ocorrido (Macedo, 2015, p.17). Há outro mito/rito que lhes é mais profundo, e mesmo deslocados de seu lugar original é perpetuado, dele tratarei adiante.

Os rituais que envolvem canto e dança são demarcadores importantes nas sociedades indígenas, na perpetuação de sua existência e na luta pela terra, constantemente invadida. $\mathrm{O}$ atual mandatário ${ }^{2}$ do poder central do Brasil, afirmou que o "interesse na Amazônia não é no índio, nem na porra da árvore", flagrante ataque a Constituição Federal, passível de criminalização, para um presidente, pois como diz umas das cláusulas pétreas, da Constituição, são bens da união as terras tradicionalmente ocupadas por índios e as áreas de preservação, como a Amazônia. O presidente disse que não protegerá elas, pois vai entregar a mineração ${ }^{3}$. Um crime realizado por quem devia proteger.

\footnotetext{
${ }^{2}$ Família de milicianos conforme Deputada Joice Hasselmann [PSL-SP], Jornal Correio do Povo, 22/10/2019, "Joice ameaça processar irmãos", p. 4.

${ }^{3}$ Art. 231. São reconhecidos aos índios sua organização social, costumes, línguas, crenças e tradições, e os direitos originários sobre as terras que tradicionalmente ocupam, competindo à União demarcá-las, proteger e fazer respeitar todos os seus bens.

$\S 1^{\circ}$ São terras tradicionalmente ocupadas pelos índios as por eles habitadas em caráter permanente, as utilizadas para suas atividades produtivas, as imprescindíveis à preservação dos recursos ambientais necessários a seu bemestar e as necessárias a sua reprodução física e cultural, segundo seus usos, costumes e tradições.

$\S 2^{\circ}$ As terras tradicionalmente ocupadas pelos índios destinam-se a sua posse permanente, cabendo-lhes o usufruto exclusivo das riquezas do solo, dos rios e dos lagos nelas existentes.

$\S 3^{\circ} \mathrm{O}$ aproveitamento dos recursos hídricos, incluídos os potenciais energéticos, a pesquisa e a lavra das riquezas minerais em terras indígenas só podem ser efetivados com autorização do Congresso Nacional, ouvidas as comunidades afetadas, ficando-lhes assegurada participação nos resultados da lavra, na forma da lei. $\S 4^{\circ}$ As terras de que trata este artigo são inalienáveis e indisponíveis, e os direitos sobre elas, imprescritíveis.
} 
Os cantos são uma prática ritual que ocorre em momentos e lugares específicos, funcionando com uma linguagem que articula o jogo semiótico entre animalidade e sociabilidade, natureza e cultura (Borges 2015, p. 26). Estudos indicam "a importância da festa (amjikin) nos processos recentes de resistência étnica dos índios Krahô (Mehi)" (Borges 2015, p. 15). O autor indica dois nomes ao grupo Krahô e Mehi. E percebe que a aldeia "ancestral dos Mehi localizava-se nas proximidades de um dos pés-do-céu (kôikwa krat)" (idem), mito de origem que dá sentido a localização atual e antiga da Aldeia, mesmo que alterada, sua versão sobre o mito se perpetua no novo lugar em que estão em "reserva" da Funai.

O "kôikwa krat é uma dimensão no espaço-tempo onde o patamar celestial (kôikwa) toca a terra (pjê) e a terra toca o mundo subterrâneo (krowkôti)" (Borges 2015, p. 15). Um lugar de interação de humanos e não humanos, um lugar de sacralidade que serve a festa a qual se apresenta. O estudo indica que esse lugar "do pé-do-céu" é reconhecido e ensinado no contexto cultural Krahô, "como fonte da energia vital, a origem do movimento e o conhecimento do Cosmos"(Borges 2015, p. 15). Há aqui uma interação direta entre o universo mítico e o lugar, espaço, real onde se assenta as aldeias dos Mehi. Como destaca o imaginante os polos diurno, na imagem do herói, e noturno, na estrutura mítica, se complementam.

A mítica Mehi indica que a "região do pé-do-céu era povoada por sujeitos nãohumanos 'donos' de saberes expressos numa linguagem" que é "muito apreciada" (Borges 2015 , p. 16). Os saberes tornam-se entes vivos nas linguagens e nos atos, que aqui destaco as danças e cantos interligados. O "espaço-tempo" onde "todas as plantas e animais sabiam cantar" (Borges 2015, p. 16), o campo de saberes está além do transcendente do "céu", está nos seres terrenos com quem os Krahô vivem, se relacionam e ocupam o mesmo lugar. Os animais e plantas cantam, tanto quanto os humanos. Outro processo importante é perceber que também os objetos criados, frutos da técnica, são fortemente agentes, para os Mehi, quando os indígenas afirmam que"não eram os únicos - havia também um Machado-Cantor (Kajré), que estabeleceu o modelo de humanidade associado à arte de cantar", o fato que o ato do machado ao tocar outras coisas é um ato de canto, carregado pelo simbolismo da mítica que marca a interação dos indígenas com seu lugar de origem, o pé-do-céu.

$\S 5^{\circ}$ É vedada a remoção dos grupos indígenas de suas terras, salvo, "ad referendum" do Congresso Nacional, em caso de catástrofe ou epidemia que ponha em risco sua população, ou no interesse da soberania do País, após deliberação do Congresso Nacional, garantido, em qualquer hipótese, o retorno imediato logo que cesse o risco. $\S 6^{\circ}$ São nulos e extintos, não produzindo efeitos jurídicos, os atos que tenham por objeto a ocupação, o domínio e a posse das terras a que se refere este artigo, ou a exploração das riquezas naturais do solo, dos rios e dos lagos nelas existentes, ressalvado relevante interesse público da União, segundo o que dispuser lei complementar, não gerando a nulidade e a extinção direito a indenização ou a ações contra a União, salvo, na forma da lei, quanto às benfeitorias derivadas da ocupação de boa fé. 
O "herói Hartãt” conduz os os Mehi "até o pé-do-céu onde viviam o Kajré, os animais e as plantas que lhes ensinaram festas e cantigas" (Borges 2015, p. 17). O herói é conduzido aos espaço mítico, mesmo ele como mito. Isso é re(a)presentado, ou seja, mantém o trajeto do grupo, e refaz o processo de resistência cultural, mesmo que deslocada de seu ponto original, mas que como indiquei, ponto no Tocantins que sempre é revisitado pelo Krahô.

"As festas vinculam os Mehi com o espaço-tempo do pé-do-céu e trazem, assim, as vozes de diferentes agencialidades não-humanas para o centro da aldeia"(Borges 2015, p. 17). A simbólica dos animais, das plantas, e do próprio espaço, refaz o sentido de existir no mundo, junto ao "pé-do-céu". Mais que isso ao consagrarem e "apre(e)nderam seus amjikin (festa, rituais)" (idem), refazem seu contínuo retorno ao umbigo de sua origem, fetas que mobilizam intensamente as aldeias a sua realização.

Os Mehi fazem uma festa, "incorporada ao seu calendário", festa que indica a “interação com os peixes no fundo de um rio” (Borges 2015, p. 18). Essa está no pé-do-céu, e me interesso por ela tendo em vista ao meu estudo sobre as águas que desenvolvo no estágio pós-doutoral. A festa "Tep me Teré”, os Krahô "encenam sua apropriação original”, na sua criação e colocação na terra, que eles vivem, e que no trajeto antropológico, sempre viveram. O deslocamento não elimina o sentido, do existir na terra. Conta o mito:

Era tempo de chuva, quando então um 'portador' (me cunã hujaren catê: "aquele que conta/diz [hujaren] a todos sobre a festa") saiu de sua aldeia em direção a uma outra. Deveria levar o convite de uma festa que sua aldeia daria, mas, no caminho, se deparou com uma cheia. Tentou atravessar o rio sobre um pedaço de pau, mas foi engolido por uma enorme sucuri e levado para baixo, para o fundo das águas. Depois de um tempo, a sucuri vomitou o índio já podre, despedaçado e as partes do seu corpo ficaram espalhadas por todo lado. O wajacá (xamã) da aldeia teve uma visão sobre o ocorrido, foi até a margem do rio e conversou com o cará - o xamã dos peixes. Logo o boto (chefe de todos os peixes) chegou ao local, ficou bravo com o ocorrido e ordenou que os peixes procurassem todos os pedaços do índio. Os peixes procuraram: os pequenos foram à cata dos pedaços pequenos (olhos, nariz, unha, dedos) e os grandes procuraram braços, pernas, cabeça. Após um tempo embaixo d'água, o Mehi foi recuperado pelos peixes, que o alimentaram. Depois de comer a comida dos peixes, o índio ficou pronto, refeito e forte. O boto então lhe pediu para ficar mais um pouco porque tinham uma festa para mostrar; que era para ele voltar e ensinar para seu povo. Os peixes então ensinaram seu jeito de dançar e transmitiram suas músicas. Fizeram a festa, que só não foi completa porque as lontras, convidadas, apareceram e quiseram comer todos os peixes. A garça também foi convidada; queria comer peixe, mas as lontras estavam acabando com tudo. A garça então matou o chefe das lontras. As demais foram embora e a garça voou. Nesse instante, dois seres Côhkrit andavam debaixo d'água e o jaú contou para o Mehi. Ele gravou tudo na sua cabeça e, escoltado pelos peixes, subiu de volta à superfície. Na sua aldeia, contou para o povo como é a alegria dos peixes e, por isso, até hoje os índios Krahô fazem a festa de Tep me Têre". (Borges, 2015, p. 21-22).

A própria festa é preparada antes, com danças de informação, que lembram o período 
das chuvas, período de clima mais ameno, período também em que os Krahô, foram atacados pelos fazendeiros em sua terra natal. Um "contador de história" faz as vezes dos cantos e das danças de preparação, "aquele que conta/diz [hujaren] a todos sobre a festa", que é representado por muitos dançarinos que conta as várias aldeias o momento que está por vir. Mas "se deparou com uma cheia", evento que indica a falta de condições de avisar os outros sobre os ataques, mas também que marca a relação do heroi com os animais e com o lugar.

O hujaren, tenta atravessar a cheia, mas foi atacado e engolido pela grande cobra da região, a sucuri. A grande cobra sinuosa e força natural que devorava também as crias do gado dos fazendeiros, carrega hujaren, para as águas profundas. Esse caminho, captura e imersão é dançado, é cantado e as músicas lembram bem esse conflito entre o heroi, o animal e o espaço (água). Bachelard (1997) diria então que nesta simbologia, ocorre a junção de dois sentidos, a morte (á agua como passagem e o próprio ato de ser devorado pela cobra), e o próprio sentido de passagem, a água como fluído de passagem. Necessário ao povo Krahô, tantas vezes agredido pelos não índios.

O herói Krahô hujaren, é levado para baixo, para o fundo das águas, a estrutura de descer. Ou seja, na perspectiva do imaginário Durand (2012) diria que o herói, no seu universo da dominante postural, com símbolos como tal, segue seu caminho, carrega sua fala, com a força do gladio, das armas, sendo purificador (p. 54). No entanto sucumbe a força da dominante digestiva, de descida, gesto postural, que se reflete na dança e no canto que mostra essa descida, matéria da profundidade, da água, do cálice, do cofre (Durand, 2012, p 54), devaneios das águas (de Bachelard, 1997). O que percebe-se aqui é o mito que se liga a arquétipos, mas que são pontos diferentes, pois o "arquétipo" se separa do "simples símbolo" é a "sua falta de ambivalência" (Durand, 2012, p. 54). O arquétipo possui uma "universalidade constante e a sua adequação ao esquema" (idem). O que vemos aqui se fazendo representar pode ser o arquétipo da roda pelo símbolo da serpente (ibidem).

A sucuri libera pelo vomito o hujaren, mas agora podre, em partes espalhadas. Depois de um tempo, a sucuri vomitou o índio já podre, despedaçado e as partes do seu corpo ficaram espalhadas por todo lado. Para Durand (2012, p. 219), há uma re(a)presentação do mundo dos mortos, na contrapartida do mundo do vivos, invertida, o velho, estragado, podre, torna-se então novo, sólido, rico, o regime noturno da imagem, eufemização do noturno, retribuição temporal dos erros na consagração dos méritos, a imaginação é sensível na evolução escatológica.

O xamã da aldeia na margem do rio conversa com o xamã dos peixes, e o chefe de todos os peixes ordena a procura dos pedaços, juntados os pequenos pelos peixes pequenos e 
os grandes pelos peixes grandes, e após algum tempo, foi recomposto. E ficou para festa dos peixes que deveria ser ensinada ao povo de fora d'água. $\mathrm{Na}$ festa da água as lontras comem os peixes, a garça como a lontra chefe, todos vão embora. Mas fora d'água isso não ocorre pois sabem como foi la dentro. Na aldeia o povo repete a alegria dos peixes, os indígenas Krahô fazem a festa de Tep me Têre (cf. Borges, 2015, p. 21-22). As danças sinuosas e com momentos eletrizantes, acompanhadas pelos cantos que marcam os tempos vividos no mito, demonstram a força da negação do inimigo envolvente, mas marcam também, a superação mítica do mesmo. A morte, descida e escanção, do herói, que traz a dança dos peixes para sua aldeia atual, repetida e repetida, na Festa das Sementes (todo ano). Ensina aos mais novos o fato, da reestruturação, mas revela também que a mítica ancestral dá o valor ao ato de seguir e de resistir. As alterações do lugar do pé-do-céu, dos animais, dos ritos, não minoram a força inicial dos arquétipos constituidores, só os reforçam, com novos roupagens míticas.

Esse processo "revela a habilidade destes indígenas em dar seu próprio sentido às coisas toma-das dos outros", mas também o sentido de de morrer e reviver, no ato da luta quando de expulsão de suas terras, unindo a luta ao que consideram "boa vida" (Borges, 2015, 38). Os Krahô manipulam sua cultura "em face ao colonialismo da sociedade nacional", carregando de valor simbólico "sua identidade", na busca de manter e "retomar o controle do seu próprio destino", afirmam sua cultura pela "manutenção de ritos e instituições sociais tradicionais como parte integral de sua resistência política à perda de terras, recursos e condições de autodeterminação" (Borges, 2015, pp. 38-39).

\section{Os angoleiros}

$\mathrm{O}$ ato de resistir parece menos reconhecido, mas ele existe e é eficaz também nos grupos poliétnicos. Há uma persistência das identidades (Barth, 1998) e nas sociedades tradicionais as mudanças levam mais tempo, sendo fruto de alteração territorial, ruptura do equilíbrio ecológico e ruptura na estabilidade populacional, situações mais comuns em sistemas poliétnicos (citadinos).

As fronteiras étnicas são os demarcadores que possibilitam a identificação dessas etnicidades, pois definem grupos étnicos e não a matéria cultural (fronteira social), na interação é que aparece manifesta a pertença e a exclusão, não são simples ou baseadas em ocupação de territórios exclusivos, as fronteiras organizam relações sociais e comportamentais complexas, compartilhamento de critérios de avaliação e julgamento ("é nosso, é do outro"), há conjunto sistemático de regras dirigindo os contatos interétnicos. As prescrições são seguidas, há concordância com código de valores, há preservação de partes da 
cultura contra possíveis modificações, impedimento de interações interétnicas. Os grupos afirmam sua etnicidade na auto atribuição ou atribuição por outros, seguem uma atribuição categórica que identifica a pessoa por sua presumível origem e ambiente, as variações ecológicas marcam, exageram as diferenças e são usados como sinais e emblemas de diferenças, mas diferenças radicais são também minimizadas (Barth, 1998).

Os cantos, as músicas e as danças tornam-se uma prática ritual "que ocorre em momentos e lugares específicos, funcionando com uma linguagem que articula o jogo semiótico entre animalidade e socialidade, natureza e cultura" (Borges 2015, p. 26). Não obstante que estas divergências sejam processamentos apenas esquemáticos, para compreensão de atributos que as constituem, pois tais separações não ocupam o imaginário, pelo menos destes dois grupos que eu destaco. Cabe dizer que essa linguagem fluida do canto, musica e dança, marca a forma de estar no mundo destes grupos, diferente de um processo racionalizante de identificação de música erudita e popular, desenvolvida pela sociedade poliétnica eurocentrada.

$\operatorname{Re}(a)$ presento pelo grupo poliétnico (citadino) os angoleiros, capoeiristas. Há um imaginário mítico que cria e repete o todo da Capoeira Angola. A capoeira, da qual sou praticante a mais de 24 anos, é uma arte de resistência cultural, sendo jogo, brincadeira, luta, mas também dança, canto e música. O capoeirista equilibra a malícia, a mandinga e a malandragem (Barbosa, 2005; Accurso, 1995), sempre respeitando o outro capoeirista.

O mestre na Capoeira Angola e a própria capoeira ensina, que somos "viajantes nestas terras, oriundos dos quatro cantos do mundo, acolhidos e amparados pela Grande Mãe Brasil” (Hentges, 2016, p. 134). A elucidação imaginante de Angelita Hentges (2016) identificou que estes viajantes "ainda habitantes dos porões da nação", sempre são e foram "relegados ao esquecimento, pois as instituições insistem em desconhecer", abrem o caminho a golpes ligeiros e medidos de capoeira, tanto na roda como na vida. Sua forma de agir, se refaz e se apresenta nos "modos e formas de existir que carregam ecos de outros tempos e que pulsam em cada pequeno e excluído grupo que convive ao som daquilo que foi... em cada neto que cita seu avô, e em cada nova geração que carrega a geração que lhe gestou" (Hentges, 2016, p. 134). Esse eterno retorno aos ancestrais possibilita o existir, e constitui o ritual nas rodas de Capoeira Angola.

O ritual, pois não é um simples esporte ou luta, e aqui identifico a Capoeira Angola, é baseado na ideia de interação e parceria entre dançantes. Nessa dança vemos passos básicos (Barbosa, 2005), a parada, a ginga, a negativa, o role, o $a u$. A partir dessas surgem o desarmar, ludibriar, desequilibrar e golpear o adversario (Barbosa, 2005). A dança é uma conversa entre 
corpos mantida musicalmente pela bateria e suas músicas, cantadas e tocadas (Accurso, 1995; Barbosa, 2005). A criação como luta, da qual não abre mão como forma de expressão a coloca na condição de resistência de forma imediata. No entanto ao se dedicar a ensinar uma resistência cultural ela se torna força mítica de um grupo carregada de significados articulando no "jogo semiótico" a presença de reflexões sobre formas de sociabilidade, sobre interações com a natureza e mantenedora cultural de um certo grupo (Borges 2015).

Há sempre uma sequencia de movimentos, mas que não seguem sempre a mesma ordem, mas que seguem sim um significado. "A ginga - homenagem à Rainha Nzinga, se encontra colada no riso zombeteiro dos jogadores durante as jogadas, nos movimentos rápidos e invertidos, nos jogos de pés, na dança dos corpos" (Hentges, 2016, p. 131). A ginga, lembra sempre a Rainha Nzinga, ou Jinga, que era uma guardiã do seu povo, usando da mandinga e enganação manteve os europeus afastados de seu povo no processo de escravização (Accurso, 1995). "A ginga carrega o mistério da criação" (Hentges, 2016, p. 131). Há um mito gerador e perpetuado no ato em si, na música que o gera, na sequencia de passos de dança que a mantém como materialidade dessa imagem.

A ginga sedimenta e cadencia, como o significado - "o caneco de cabo longo, usado nos engenhos de banguê para baldear o caldo de uma tacha para outra" (Barbosa, 2005, p 84). Os dois sentidos comportam o mesmo movimento, cuja mítica ligada a África inspira os praticantes. A ginga é um movimento de vai-vem e torna-se o passo básico na gramática da capoeira (Barbosa, 2005, p 84). A ginga é cadenciada pelo berimbau condutor da roda, ou seja, momento e lugar específico, funcionando com uma linguagem (Borges, 2015). “A ginga é o tesouro que cada jogador-capoeirista conquista para si” (Hentges, 2016, p. 131).

“A ginga carrega as muitas faces de Exu - O Senhor dos Caminhos, e através dele traz a atuação indireta, que induz, seduz e conduz, invertendo a luz em sombra e a sombra em luz" (Hentges, 2016, p 131). A força dessa entidade é a força de uma ruptura, "rompe-se com o limite do estabelecido, subvertendo a ordem do espaço e do tempo, contradizendo a lógica do instituído". Ao perceber essa ruptura percebe-se o efeito presente e consternador da capoeira na interação com o espaço poliétnico cujo "padrão de normalidade" é o padrão branco eurocentrado. Essa ruptura na roda e na vida "gera movimentos e possibilidades, invertendo o que seria "natural", pois está no vórtice criativo das mudanças". O Exú é ginga e por tanto abertura e tradução. A ginga "comporta o poder feminino, re(a)presentando-o como o segredo, e tornando-se uma das faces da existência cíclica que o jogador-iniciado passa a conhecer" (Hentges, 2016, 131). A ideia de iniciação como nos processos de interação cosmogônica cria um ethos de dançarino para a vida, a partir de um modelamento que aparece no angoleiro. " $\mathrm{O}$ 
segredo é elemento que surge na mitologia da criação do mundo e dos humanos pelas mãos de Orunmilá, o Senhor dos Destinos" (idem). Apresentar o senhor da advinhação do futuro que é calcado no passado, que floreia a frente de seu companheiro de roda ou de seu opositor na vida, que surpreende, no movimento sinuoso, do corpo e do pensar do angoleiro, que surpreende, pois dentro de sua cultura está formado para isso.

A ginga "como Orunmilá é um eco do início dos tempos que guarda e revela o futuro, que pode ser metaforizado pelo tesouro" (Hentges, 2016, p. 131). aqui se apresenta o passado e o presenta, dançando, a vida do angoleiro, molejante, irreverente, mas centrado em uma destino possível, que é fruto de um passado percebível. "A busca pelo tesouro", nas rodas e na vida, "impulsionam, é símbolo da vida interior, que somente uma jornada arriscada possibilita atingir" (idem). A dança contínua e exuberante do jogador de Capoeira Angola permite que se lance sem medo ao futuro, pois é tesouro arriscado, mas possível de ser alcançado, assim como ter persistido na vida, como os africanos arrastados para a América que ainda estão aqui, vinculados ao umbigo original, que está lá, dançam como "o destino, nas encruzilhadas da vida, certos do amparo da Grande Mãe" (Hentges, 2016, p. 131). A encruzilhada é a forma de re(a)presentação do Exú.

A ginga carrega a "malícia". A "malícia" na Capoeira Angola, positiva e negativa, significa a sagacidade artística e a índole da malandragem, articula as dobras do “jogo”(dança), catalisa e media as tensões, de energia e de gestos (Barbosa, 2005, p. 85). Há uma ambivalência na Capoeira Angola, ramificada, no toque dos berimbaus, no ditar das canções, no avanço e recuo dos corpos. O movimento reverte na série que estabelece o dialogo corporal, com ousadia, criatividade e variações de passos (Barbosa, 2005, p. 84). Os três berimbaus, com três toques diferentes, conjugados aos pandeiros (2), agogô, reco-reco e atabaque, craim nuances fluidas que os corpos seguem e refazem, numa "sucessão de tons e semitons que desestabilizam a polarizada estrutura inicial e enchem a roda de energia sensual e sedutora" (Barbosa, 2005, p. 85). Aqui as músicas/cantos lembram muitos de seus herois, relevo ao regime diurno da imagem (Durand, 2012), do nordeste e de outros recantos do país conforme os lugares em que estão os dançantes. A figura de Lampião (na "A pisada de Lampião" - domínio publico), personagem mítico "heroi e anti-heroi", simboliza o lado daquele que subverte a ordem instituída. (Exemplo: Tum, tum, tum (Coro) // Olha a pisada de Lampião // Eu só queria estar agora // No reduto de Lampião // Pra ver a capoeira // Rebolando no salão // Cantando "Mulé Rendeira" // Dando vivas a Lampião. // Mestre Bola Sete - Barbosa, 2005, p. 85).

Usa-se de metonímias calcadas em visões do que se refugia na luta contra a 
dominação no período escravista e na atualidade das políticas que só consagram os mais ricos e poderosos. As metáforas das tessituras socioculturais da capoeira (Barbosa, 2005, p. 86 corrido [música que é repetida várias vezes e permite o jogo, diferente da louvação e da ladainha] \{Accurso, 1995\}- "Quem vem la," domínio publico // Quem vem la sou eu. // Berimbau bateu, Angoleiro sou eu (Coro) // Cavernoso sou eu. // A cancela bateu. // Montado a cavalo, fumando charuto, coberto de luto, sou eu Brevenuto // Eu venho gingando, chinelo arrastando, lenço no pescoço, navalha no bolso).

A ambivalência e as dissimulações linguísticas, "escondidas nas letras das ladainhas, chulas e corridos" (Barbosa, 2005, p. 86), são expressões do ente, em sua plenitude, na demonstração da liberdade, mesmo durante o período da escravização, apresentadas nos movimentos sinuosos e invertidos, nas rasteiras, na ginga e improvisação do jogo de Angola, gramática apresentada a partir de sua matriz, na lógica da cultura, "lidos e interpretados", como traços diacríticos carregados de significados na gramática corporal da consciência étnica (ex: "Da no Nego" - Domínio público: Da, da, da no nego (Coro) // No nego você não dá! // Mas se der vai apanhar).

O corpo maleável do angoleiro, os movimentos, sua energia, interagem com o ritmo do berimbau e dos outros instrumentos, numa coreografia criadora, com efeito lúdico, na dança das palavras, nos vários significados linguísticos, históricos e culturais, das letras das cantigas, empolgadas pela sensualidade da dança da Angola. A dança da Capoeira Angoila manifesta-se através da energia da musica, dos cantos e dos corpos. Alterna ginga e movimentos eletrizantes, na linguagem corporal, com gramática própria, evidenciados pelos enigmáticos levantares de pernas braços e rodopios que quase arrastam-se pelo chão, quase como cobras, gatos, macacos, como o vento batendo nas folhas das árvores, como os redemoinhos das águas em rios pedregosos, dialogo com "manha" dos angoleiros (Barbosa, 2005, p 91-92). A dança é cosmogônica na matriz ancestral africana, aparecem no "corpo fechado" (madinga), e rituais de início de jogo, e nos cantos. Ex.: "Girar o Mundo," (domínio publico) - Vou girar o mundo,// Ô girar, ô girae // Cada salto é uma reza // Cada golpe é uma canção // O que leva vantagem // É a mandinga do negão.

A Capoeira Angola é conectada as cosmovisão de matriz africana (barbosa, 2005, p. 91-92). Aparece Oxóssi (o caçador), Xango (o exuberante e corajoso deus do raio e do trovão), Iansa (senhora das matas e dos ventos), Ogum (parceiro de Exu) e Exu (o mensageiro da palavra). Sacralização preparada antes da roda, preparação que os mestres antigos e novos fazem , comendo comidas especiais antes das rodas. E as músicas e danças na roda apresentam vivamente estas relações mais miticas, no contexto do regime noturno da imagem 
(Durand, 2012). Ladainha "Orixas da Bahia," (Mestre Bola Sete - Barbosa, 2005, p. 93: Xangô, rei de Oyó // O Exu é mensageiro // Omolu, Senhor Sâo Bento, // Oxóssi, santo guerreiro. // Iansa das tempestades, // Janaina, rainha do mar, // Nana, Iyaba Senhora, // Mãe de todos os orixas; // Ogum, o deus da guerra, // Oxala, santo de fe, // Olorum, o rei supremo, // O Senhor do candomble).

O angoleiro evoca Exu, para a posição intermediária e instável, como mensageiro e interlocutor entre céu e terra, entre bem e mal, entre certo e errado. Ao fazê-lo, o faz na roda, pois é um círculo fechado que arrecada as forças que entrelaçam os humanos aos encantados, entre terra e água, e assim as ligações que a musica "ladainha", faz ao iniciar um jogo, ou mesmo a roda como um todo. As outras entidades vão se encaixando nos movimentos dançados na roda. O facão de Ogum, cantado e dançado no movimento de braço em forma de haste, que desce e sobe em meio a ginga. O espelho de Oxum que marca as mãos espalmadas abertas frontalizando movimentos junto aos bailarinos. E assi $\mathrm{m}$ sucessivos "golpes" e movimentos entoam as formas de ser destas entidades pelo seu poder e por suas "armas". A roda fica encantada, os relações que se travam ali estão então fora do mundo conhecido, estão envoltas pela sacralidade.

Rodas protegidas pela força das entidades, que se fazem aparecer em cada corpo dançando, dançam ao seu protetor, ao envocado no momento do início do jogo, estes corpos dançam os as forças naturais que marcam a cosmovisão africana. Essa expressão do vivido entoa sempre e perpetua sempre o pensamento étnico de seus criadores e que são preservadas ainda na Capoeira Angola. Não é uma ato descolado do ser africano no Brasil, é a evocação deste ser, sempre presente. O enegreSer, como nos diz uma pesquisadora de dança afro Juliana Coelho (2019- dissertação defendida em Artes Visuais na UFPel - Tornar-se negra: As danças afro no processo de autoidentificação e empoderamento étnico de uma professorartista). $\mathrm{O}$ estudo realizado sobre o grupo em que desenvolvo o meu saber sobre a Capoeira Angola indica que

\footnotetext{
na roda da vida reinam os deuses e as deusas, travando lutas e travando festas, regozijando-se sob o sol, guerreando sob a lua, ao som do berimbau, fazendo de nós raízes, moldados em essência pelo ar, pela água, pelo fogo, pela terra, forjados no dia e na noite... e no decorrer de tudo haverá sempre um novo começo, porque fim e começo são a mesma coisa... e disto tudo emerge um tesouro: um novo homo e uma nova humanidade! (Hentges, 2016, p. 135-136)
}

Compreender a roda da vida, como uma dança diária dos angoleiros, jogadoresdançadores-iniciados na Capoeira Angola, é compreender sua mítica ligada aos "deuses e as 
deusas". A vida é para lutar, festejar, guerrear "ao som do berimbau". A iniciação é fruto de uma mítica com raízes profundas, que fazem os capoeiristas angoleiros se constituírem “moldados em essência pelo ar, pela água, pelo fogo, pela terra, forjados no dia e na noite". Como a roda da vida "haverá sempre um novo começo, porque fim e começo são a mesma coisa", uma dança contínua embalada ao som da bateria que recria sempre uma "nova humanidade" (Hentges, 2016, p. 135-136).

A existência na polietnia citadina da Capoeira Angola, poderia ter relegado aos seus praticantes o aceite da massificação acachapante do universo do capital. No entanto por possuir este imaginário fermentador profundamente enraizado na africanidade e sua simbologia. Os símbolos lhe são o sentido de existir. Há formas novas nessa interação com o universo eurocentrado. Transformando a capoeira em uma mero movimento de corpos, que longe, muito longe estão na performance da dança-iniciática do angoleiro. Mítica existencial que a configura e que os dançarinos angoleiros preservam como um tesouro, como um segredo e que para conhecer há que se engreSer, ou seja, encontrar o africano que carrega em si. Cuja nova forma de fazer, a dita capoeira contemporânea, não faz ideia do que seja, deformam corpos e formas de entender o mundo, pois não carregam as raízes.

O mundo africano carrega essas, que os mantém vivos até o momento, contra as políticas de branqueamento eurocentradas. Assim como a etnicidade africana, há também os universos tradicionais, normalmente rurais, dos quilombolas, dos pequenos agricultores familiares e dos ameríndios. Estes podemos dizer a partir de Barth (1998) são grupos tradicionais, com traços diacríticos fortemente apresentados cujas raizes ancestrais são muito antigas.

O "espaço e tempo" formaram um novo "cenário", mas a cultura não desaparece, ela dialoga "entre si”, a "cultura é processo de geração e regeneração, porque é imemorial”, reorganizada "de informações, sabedorias tradicionais", "vital para a criação de vínculos comunitários dentro de um contexto global'(Pinto, 2008, p. 7).

\section{Considerações}

Quando penso nos mitos como uma forma diferenciada de cognição, aceito "o desafio" de juntar e ser capaz "de perceber o lugar do regional no nacional, do local no universal" (Pinto, 2008, p. 10), que neste estudo apresento nas míticas, dos símbolos originais e as formaram a partir da investigação da externalização dessas, que eu chamo de apresentação.

Estudo desses contextos étnicos, tanto no espaço poliétnico citadino, quanto nos 
contextos de grupos étnicos tradicionais (Barth, 1998) demonstra a persistência simbólica, que possibilita manter a própria tradição e com isso perpetuar sua identidade étnica. Foquei nas "danças afro" desenvolvidas no sul do Brasil e algumas manifestações dançadas dos ameríndios do sul e do norte do Brasil. Estas danças são hoje reconhecidamente danças de expressão da persistência, das formas de pensar e agir, com/no mundo, dessas comunidades, na contraposição ao contexto simbólico trazido pelos invasores europeus, transformando estas danças em manifestações socioculturais de resistência dos afro-americanos e ameríndios.

$\mathrm{Na}$ busca de entender esses contexto sigo a aura do imaginário, identifico nestes dois contextos analisados arquétipos, como "a roda", que é "o grande arquétipo do esquema cíclico", percebida na sua "significação imaginária" no símbolo/mito dela na ginga em roda na Capoeira Angola, ou no símbolo/mito da "serpente" dos Krahô, são apenas símbolos "do ciclo, símbolo muito polivalente", onde o

os arquétipos ligam-se a imagens muito diferenciadas pelas culturas e nas quais vários esquemas se vêm imbricar. Encontramo-nos então em presença do símbolo em sentido estrito, símbolos que assumem tanto mais importância quanto são ricos em sentidos diferentes (Durand, 2012, p. 62).

\section{Referencias}

ACCURSO, Anselmo da Silva. Capoeira: um instrumento de educação popular. Porto Alegre: Edição Independente, 1995

BACHELARD, Gaston, A água e os sonhos: ensaio sobre a imaginação da matéria. (Coleção Tópicos); [tradução Antônio de Pádua Danesi]. - São Paulo : Martins Fontes, 1997.

BACHELARD, Gaston, A poética do devaneio. [tradução Antônio de Pádua Danesi.] - São Paulo: Martins Fontes, 1988.

BARBOSA, Maria Jose Somerlate . Capoeira: A gramática do corpo e a dança das palavras. Luso-Brazilian Review 42:1 ISSN 0024-7413, by the Board of Regents of the University of Wisconsin System (pp. 78-98), 2005

BARTH, F. Grupos Étnicos e suas fronteiras. In: POUTIGNAT, P. Teorias da etnicidade. Seguido de grupos étnicos e suas fronteiras de Fredrik Barth, Philippe Poutignat, Jocelyne Streiff-Fenard. Tradução de Elcio Fernandes. São Paulo: UNESP, 1998.

BORGES, Júlio César. Peixes, Lontras e Arraias: resistência étnica dos índios Krahô através da festa. In Revista Anthropológicas, Ano 19, 26(1):15-44, 2015

CASSIRER, Ernst. Antropologia filosófica. Introducción a una filosofía de la cultura. $5^{\text {a }}$ ed., Cid. Do México: Fondo de Cultura Econômica, 1968

CASSIRER, Ernst. Linguagem e Mito. $3^{\text {a }}$ ed., São Paulo: Perspectiva, 1992 
DURAND, Gilbert. Campos do Imaginário. Lisboa: Instituto Piaget, 1996 (Longínquo Atlântico e próximo Telúrico, imaginário lusitano e imaginário Brasileiro, pp 197-204).

DURAND, Gilbert. Estruturas Antropológicas do Imaginário. Introdução a Aquetipologia Geral. São Paulo: Martins Fontes, 2012.

DURAND, Gilbert. $O$ imaginário. Ensaio acerca das ciências e da filosofia da imagem.

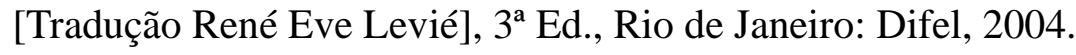

HEIDDEGER, Martim. Introdução a Metafísica, Rio de Janeiro,:Tempo Brasileiro, 1966

HENTGES, Angelita. Imaginários Fermentadores de Educação nas Rodas de Capoeira Angola do Accara: Elementos de uma Educação Circular. Tese (Doutorado em Educação) Programa de Pós-Graduação em Educação, Universidade Federal de Pelotas, Pelotas, RS. 136f, 2016

LÉVI-STRAUSS, C. O Cru e o Cozido (Mitológicas 1). São Paulo: Brasiliense, 1991

MACEDO, Aurinete Silva. Saberes tradicionais Krahô e educação escolar indígena: um diálogo possível na escola indígena 19 de abril. (Oror Prof. Dr. Francisco Edviges Albuquerque) Dissertação Mestrado em Ensino de Língua e Literatura - Universidade Federal do Tocantins - PPGL, Araguaína: UFT,130f, 2015.

PINTO, Marilina C. Oliveira Bessa Serra . A Amazônia e o imaginário das águas. Trabalho apresentado na mesa-redonda Populações Amazônicas do 1॰ Encontro da Região Norte da Sociedade Brasileira de Sociologia, em 16/10/08 promovido pelo Programa de PósGraduação em Sociologia PPGS/UFAM. Manaus, 2008

PITTA, Danielle P. Rocha. Imaginário: derivações de métodos no Brasil. Téssera. Uberlândia, MG, v.1, n.1,p.154-172, jul./dez. 2018 